Bull. Iraq nat. Hist. Mus.

\title{
MOLECULAR CHARACTERIZATION OF ANISAKID NEMATODES HYSTEROTHYLACIUM SPECIES FROM JAPANESE THREADFIN BREAM NEMIPTERUS JAPONICUS (BLOCH, 1791) (PERCIFORMES, NEMIPERIDAE) FROM IRAQI MARINE WATER FISH
}

\author{
Majid Bannai * Muna Mohammed Jori ** and Shokoofeh Shamsi*** \\ *Department of Marine Vertebrate, Marine Science Centre, University of Basrah, Iraq, \\ Basrah, Iraq. \\ **Departments of Veterinary Microbiology and Parasitology, College of Veterinary Medicine, \\ University of Basrah, Basrah, Iraq. \\ ***School of Animal and Veterinary Sciences, Charles Sturt University, Wagga Wagga, New \\ South Wales 2678, Australia. \\ *Corresponding author: majidbannai65@gmail.com
}

Received Date: 08 May 2021, Accepted Date: 25 July 2021, Published Date: 20 December 2021

\begin{abstract}
The present study provides a new insight into valuable information on the diverse structure of the Anisakid population and discusses the limited species richness in the Nemipterus japonicus (Bloch,1791) (Perciformes, Nemiperidae). The fishing area consists of various locations in the Arabian Gulf (29 $\left.5803300 \mathrm{~N} 48^{\circ} 28020 \mathrm{E}\right)$. A total of 315 marine fish were examined, $(n=287)$ were infected. Larval stages $(n=763)$ encysted within the mesenteries peritoneum and viscera of fish organs were isolated, with a prevalence of $91.11 \%$ of infection and, the intensity was 2.65. Molecular analysis was carried out on thirty individuals who have examined the morphology and showed some appearance differences, by amplifying internal transcribed spacers ITS and ITS-1 of nuclear rDNA (rDNA) by PCR using the primer sets NC5/NC2 and SS1/NC13R of thirteen DNA products. Evolutionary analyses were conducted in MEGA X. based on the identity percentage in the GenBank database showed that they belong to anisakid nematodes, in particular, they belong to eleven distinct taxa within the Hysterothylacium Ward \& Magath, 1917 (Rhabditida, Raphidascarididae) and one identified species H. amoyense (Hsü, 1933) Deardorff \& Overstreet, 1980. The current study records eleven species that belong to a genus of Hysterothylacium; some of the alignment of sequences polymorphisms reveals new different individuals of larvae species that may be adopted as new species if their adult stage is detected, and $N$. japonicus fish considered as a new host record. The current study provides some insights on the systematic taxonomy of these parasites, in addition, it supports similar studies that have been published elsewhere.
\end{abstract}

ABSTRACT

Keywords: Anisakid, Arabian Gulf, Molecular characterization, Nemipterus, Japonicus. 
Molecular characterization of anisakid nematodes

\section{INTRODUCTION}

Nemipterus japonicus (Bloch,1791) (Perciformes, Nemiperidae) is commonly known as the Japanese threadfin bream, it is a marine fish native to the Pacific and Indian Oceans (Froese and Pauly, 2021). Nematodes have a worldwide distribution and may include over 1 million species, they are one of the most speciose taxa, with 256 families, and 40,000 species that are known from freshwater, marine, and terrestrial habitats (Anderson, 2000). The richness of the parasitic fauna varies according to the spatial criteria of the presence of the parasite and the host as well as their geographical distribution (Poulin and Morand, 2004). Moreover, the parasite distribution is also impacted by the level of host specificity, which can vary greatly (Krasnovydm et al., 2020).

In the past 30 years, comprehensive studies on marine fish parasites in Iraqi marine waters have been conducted to increase the understanding of the biodiversity of these parasites, based on the morphological structures, which have been limited to the mature stage and are few due to incomplete growth to the adult stage, and because of the abundance of larval stages targeted this group of parasites to show the diversity and genetic variation in the study region. Since there is a bias towards certain groups of parasites, especially towards larger species (Moravec, 2004; Ghadami et al., 2017; Bannai, 2018).

As for studies on fishes of the Arabian Gulf, only a few papers have been previously published. From 1977 to 2013 in different regions of the Arabian Gulf on the coasts of the United Arab Emirates, Qatar, and Iran (Al-Salim et al., 2010). According to Froese \& Pauly (2016) over 200 species of fish are found in Iraqi marine waters, many of which are edible; however, our knowledge of their parasites is poor. Although there have been some reports on the presence of Hysterothylacium in Iraqi marine fish, most of these are based on morphology only, providing a limited morphological description that makes specific identification difficult (Ali et al., 2014). However, it needs to be updated to know more about the species and the effect of the environmental changes in regards to the increasing temperature and climate change, these conditions are important to the distribution of this type of parasites (Moravec, 2004).

The recent important advanced studies have been conducted on the same regions, these studies have provided more important and detailed information (Dadar et al., 2016); ( Nematollahi et al., 2018) Iran coastal water; WoRMS (2021) listed 90 accepted species of the genus Hysterothylacium.

The recoded of these parasite groups are of environmental, medical, and economic importance and therefore agree with the statement which says that this group deserves more research from the perspective of Iraqi biodiversity because knowledge of its parasites is still weak and unfocused, and that they have instigated more in-depth studies in nearby areas and that the integration of their study may provide a full understanding of many of the facts about them in terms of life cycles and their proliferation and there hosts (Spratt, 1997). The lack of information on the genetic diversity structure of the nematode group, which provides a limited morphology, makes it difficult to identify specifically (Ghadami et al., 2017; Bannai, 2018). 
The objectives of the present study are to determine the distribution patterns especially the occurrence of parasitic pathogenic infection of humans, as well as their location in the host, provide further information, on the genetic structure, comment on the ascaridoid populations recorded in the current study and compare and discuss the relationship with other closely related taxa in NCBI (2020) databases.

\section{MATERIALS AND METHODS}

\section{Description of the study area}

The fishing area consists of various locations in Iraqi marine waters, Arabian Gulf $\left(29^{\circ} 58\right.$ 0' $3300^{\prime \prime} \mathrm{N} 48^{\circ} 28^{\prime} 020^{\prime \prime} \mathrm{E}$ ). This area is inherently different from the rest of the Arabian Gulf, with a diverse hydrodynamic and sedimentary nature due to the presence of many hydrological effects such as the impact of Shatt Al-Arab, Karon River, Shatt Al-Basrah, wave effects, and tidal processes (Albadran, 2004). This area is special, for fish feeding and their breeding. Salinity concentrations in the region from 40 to $43 \mathrm{ppt}$, water temperature from 12.5 to $33.5{ }^{\circ} \mathrm{C}$.

\section{Specimens collection}

A total of $315 N$. japonicus fish were collected during the period from October 2019 till March 2020, and examined for the prevalence of anisakid nematodes. A variety of methods with various forms of gill nets fishing were used for fish collection. The body cavity and visceral organs were examined, the nematodes were washed extensively in physiological saline (pH 7.4) and stored in 70-95\% ethanol at $-20^{\circ \mathrm{C}}$ for isolation of genomic DNA and PCR amplification. Fish were identified according to Fish Base (Froese and Pauly, 2021). Nematodes were identified using morphology (Shamsi et al., 2013, 2015, 2016; Shamsi, 2016).

\section{Scanning electron microscope}

The specimens were fixed in $4 \%(\mathrm{v} / \mathrm{v})$ hot formaldehyde solution $\left(60^{\circ} \mathrm{C}\right)$, preserved in $70 \%(\mathrm{v} / \mathrm{v})$ ethanol, and post-fixed in $1 \%$ osmium tetroxide. The samples were then dehydrated by incubating in a graded series of acetone ethanol concentrations (1:1), (1.5 - 0.5) and absolute acetone, 15 min each (Moravec et al., 2012). A critical-point method was used for sputter-coated with gold (Moravec and Yooyen, 2011).

\section{DNA extraction and Molecular analysis}

Genomic DNA was extracted from individual larvae by proteinase $\mathrm{K}$ treatment and purified using a mini-column (WizardDNA genomic DNA purification Kit, Promega, USA), according to the manufacturer's protocol. The ITS and ITS-1 of nuclear rDNA (rDNA) were amplified by PCR using the primer sets NC5/NC2 (Forward NC5 (5'-GTA GGT GAA CCT GCG GAA GGA TCA T3') NC2 Revers (5'-TTA GTT TCT TTT CCT CCG CT-3'); and SS1/NC13R ITS-1, Forward SS1 (5- GTT TCC GTA GGT GAA CCT GCG-3), Revers NC13R 5- (GCT GCG TTC TTC ATC GAT -3) (Zhang et al., 2007; Shamsi et al., 2008), respectively, under the same conditions as described previously (Jabbar et al., 2012). The results of the amplification of PCR products were sent to study the sequence in Korea. Sequences were aligned over 1407 positions; the evolutionary history was inferred using the 
Neighbour-Joining method. The ITS sequences determined were compared (using the algorithm BLASTn) with those available in the National Center for Biotechnology Information (NCBI , 2020).

Phylogenetic relationships between characterization diversity of ascaridoid nematodes of $N$. japonicus larvae obtained in the present study and another database of NCBI species. The evolutionary history was inferred by using the Maximum Likelihood method and Tamura \& Nei model. Initial tree(s) for the heuristic search were obtained automatically by applying Neighbor-Join and BioNJ algorithms to a matrix of pairwise distances estimated using the Tamura\& Nei model, and then selecting the topology with superior log likelihood value. The tree is drawn to scale, with branch lengths measured in the number of substitutions per site (next to the branches). Evolutionary analyses were conducted in MEGA X version 10.7.1. (Kumar et al., 2018).

\section{Morphological description}

\section{RESULTS AND DISCUSSION}

A total of 315, N. japonicus (Pls.1,2) with a total length 176- 215 (195.5) mm, were examined for the detection of nematode parasite: Ascaridoidea (Superfamily), Raphidascarididae (Family), Raphidascaridinae (Subfamily) Raphidascaridinea (Tribe) and Hysterothylacium (Genus), from Arabian Gulf $(\mathrm{n}=287)$, were infected. Larval stages( $\mathrm{n}=763$ ) encysted within the mesenteries peritoneum and viscera of fish organs were isolated, with a prevalence of $91.11 \%$ of infection and, the intensity was 2.65 .

A total of 247 specimens of larval stages were isolated, with a prevalence of $57.69 \%$ of infection. The mean intensity of anisakid nematodes of frequency encountered in this survey was 5.48. Isolated anisakid larvae appeared in the current study under a light microscope cylindrically in shape and are attenuated at both ends, measuring $8-25 \mathrm{~mm}$ in length. The anterior extremity of each larva contained an insightful boring tooth that appears distinct in most examined species and four undeveloped labia, that are distinct in most diagnosed species.

The esophagus was characterized by an anterior part with a striated muscle part. A glandular ventriculus is present in most larvae and their measurements varied from one sample examined to another based on the species. The larvae were encysted within the mesenteries peritoneum and viscera of fish organs. Based on morphological characters individuals and the scanning electron micrograph of the cephalic extremity all the individuals were identified morphologically as Hysterothylacium with different species (Pl. 2). 


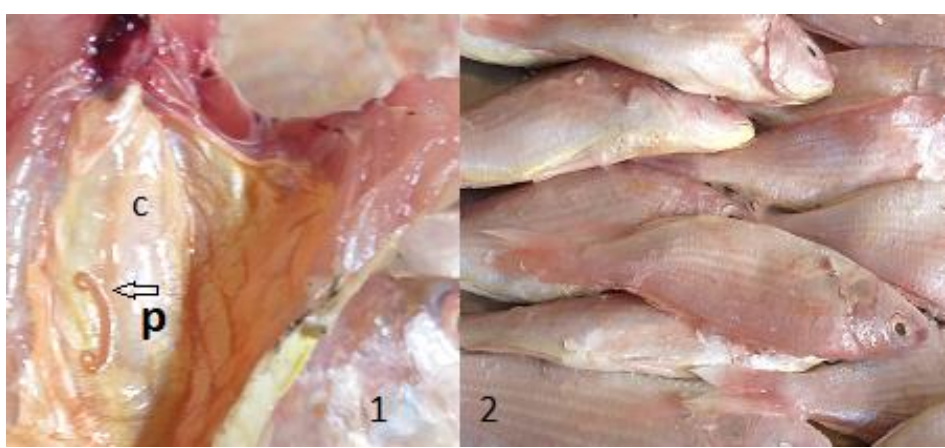

Plate (1): (1): P: larvae (L3) of Hysterothylacium amoyense; c: the mesenteries peritoneum and viscera of fish organs, (2) Japanese threadfin bream $N$. japonicus fresh specimens.

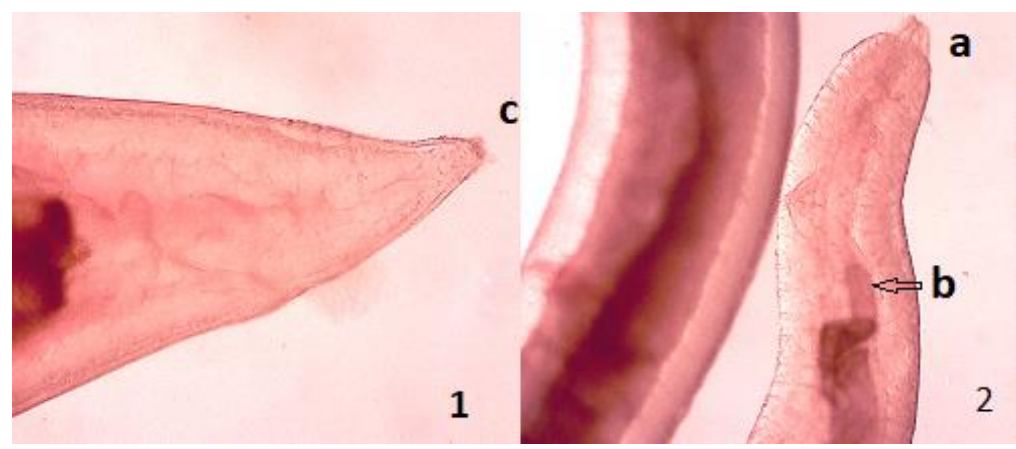

Plate (2): Larvae (L3) of $H$. amoyense viewed under a stereomicroscope; (1) Posterior region of the larval stage morphotypes tail (c), (2) Cephalic region shows mouth opening and papillae (a), glandular ventriculus viewed (b).

\section{Scanning electron microscopy $(\mathrm{Pl} .3)$}

The SEM study revealed a different pattern in the external composition of the cuticle structure. There were different formations in the composition of cuticle folds and longitudinal lateral grooves in the large cuticle among larvae (Plt. 3, 6). The general, mouth opening was surrounded by four small, cephalic papillae (two were dorsolateral and two were ventrolateral), lips not fully developed, and provided by four papillae. It is noted through the general that they belong to different types of parasites and this supports the results of genetic studies as there is a clear differentiation in the order of nitrogen base for each species as described below in Plate $(3,4)$. Also, the external composition of the cuticle layer confirms the layer of the cuticle, and the appearance of some of the composition of folds in the outer cuticle wall varies by species. The composition of the papillae was completely immature because it was in the larval stage and has not yet matured. 


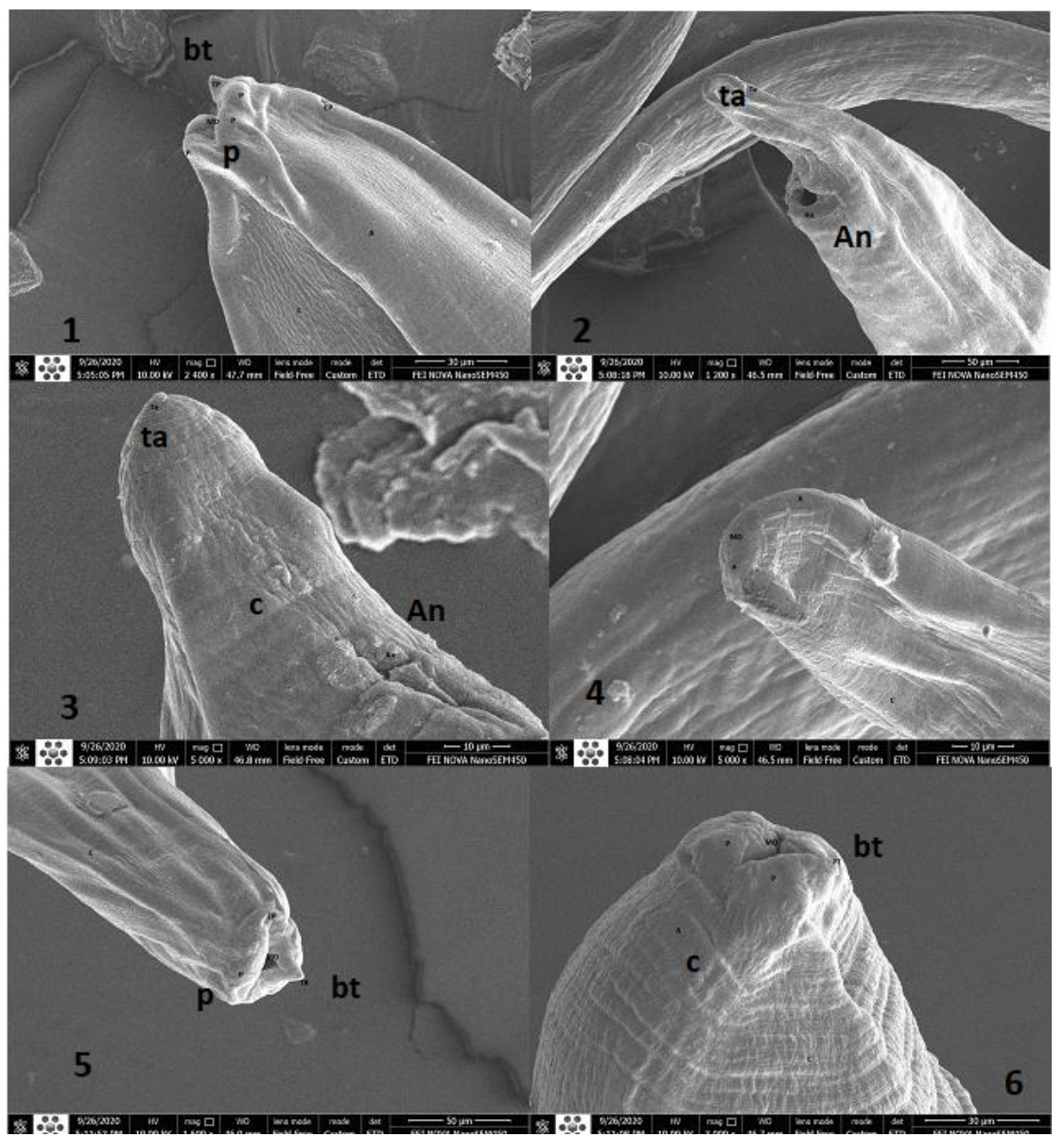

Plate (3): (1) Scanning electron micrograph of the cephalic extremity of the species Hysterothylacium sp. 1 larval stage morphotypes, A - Anterior region of the larva, $\mathrm{B}$ - a cephalic region of the larva, $(\mathrm{C}=$ cuticle of the larva $),(\mathrm{bt}=$ boring tooth $),(\mathrm{mo}=$ mouth opening $)$. $(\mathrm{P}=$ papillae. $)$; (2) Scanning electron micrograph of the posterior region of Hysterothylacium sp.1 larval stage morphotypes $(\mathrm{TA}=$ tail). (An=anus); (3) Scanning electron micrograph of the posterior region of the species Hysterothylacium sp. 2 larval stage morphotypes (TA= tail). (An=anus); (4) Scanning electron micrograph of the cephalic extremity of Hysterothylacium sp. 2 larval stage morphotypes, A - Anterior region of the larva, B - a cephalic region of the larva; $\mathrm{C}$ - Cuticle of the larva, $(\mathrm{cu}=$ cuticle $),($ mo $=$ mouth opening); (5) Scanning electron micrograph of the cephalic extremity of Hysterothylacium sp. 3 larval stage morphotypes, A - Anterior region of the larva, B - a cephalic region of the larva, C - Cuticle of the larva, ( p: papilla), (bt = boring tooth); (6) Scanning electron micrograph of the cephalic extremity of Hysterothylacium sp. 4 larval stage morphotypes, A - Anterior region of the larva, B - Head region of the larva, C - Cuticle of the larva, (bt = boring toot). (p: papilla. $\mathrm{Bt}=$ boring tooth, $\mathrm{cu}=$ cuticle, $\mathrm{mo}=$ mouth opening, $\mathrm{An}=\mathrm{anus}, \mathrm{ta}=$ tail). 


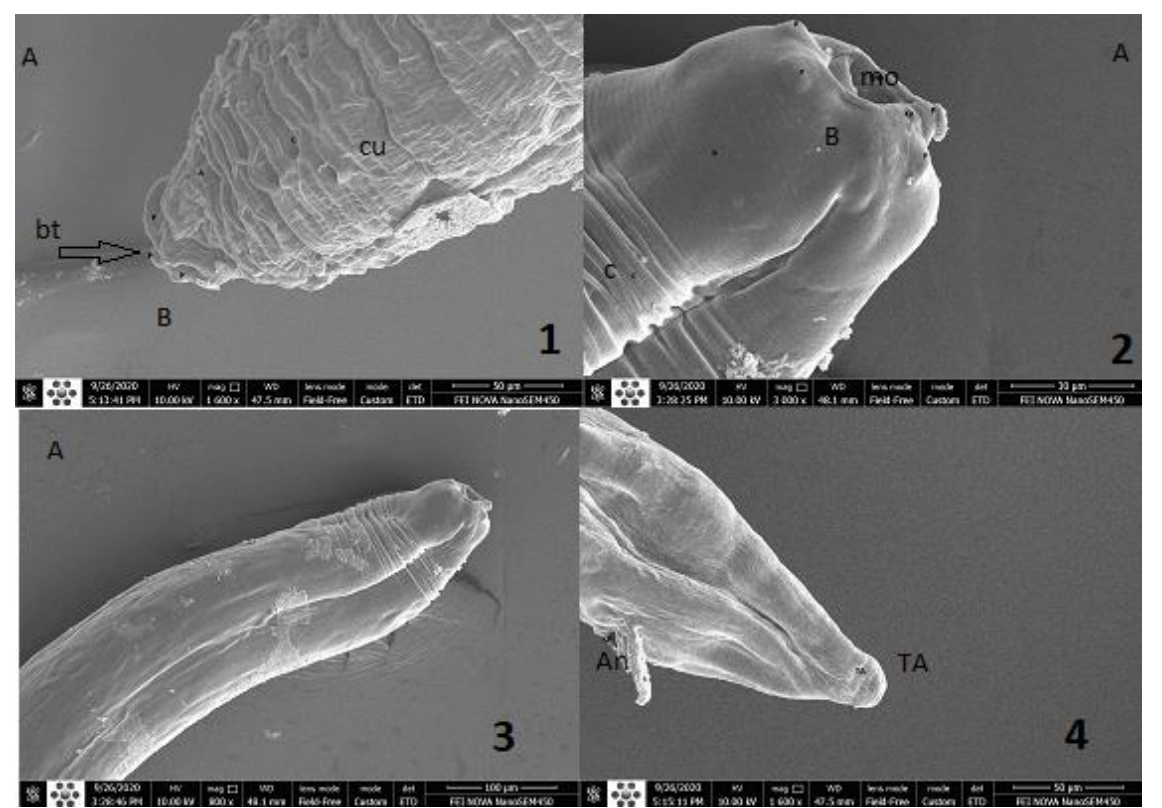

Plate (4): (1) Scanning electron micrograph of the cephalic extremity of Hysterothylacium sp. 5 larval stage morphotypes, A- Anterior region of the larva, $\mathrm{B}-\mathrm{a}$ cephalic region of the larva, $(\mathrm{C}=$ Cuticle of the larva), (bt = boring tooth $),(\mathrm{cu}=$ cuticle $),($ mo = mouth opening $)$; (2) Scanning electron micrograph of the cephalic extremity of Hysterothylacium sp.6 larval stage morphotypes, A - Anterior region of the larva, B - a cephalic region of the larva, $\mathrm{C}$ - Cuticle of the larva $(\mathrm{BT}=$ boring tooth $),(\mathrm{cu}=$ cuticle), mo = mouth opening; (3) Scanning electron micrograph of the cephalic extremity of Hysterothylacium sp.6 larval stage morphotypes. AAnterior region of the larva, B- a cephalic region of the larva, C- Cuticle of the larva, (bt = boring tooth); (4) Scanning electron micrograph of the posterior region of the species Hysterothylacium sp.6 larval stage morphotypes $(\mathrm{TA}=$ tail. $\mathrm{An}=$ anus $) . \quad(\mathrm{Bt}=$ boring tooth, $\mathrm{cu}=$ cuticle, mo=mouth opening, $A n=$ anus, ta=tail).

\section{Molecular identification of anisakid larvae}

Molecular analysis was carried out by amplifying internal transcribed spacers (ITS and ITS-1) regions of thirteen individuals. A total of 13 ITS1-5.8S-ITS2 of rDNA gene sequences of the present anisakid larvae from $N$. japonicus (Perciformes, Nemipteridae) from the Arabian Gulf off Iraq. Where deposited in the GenBank under the accession numbers (MW94896, MW961525, MW961524, MW961517, MW961526, MW961520, MW940915, MW961523, MW961527, MW961518, MW961519, MW961522, and MW961521) respectively. while 12 ITS-1 sequences of the product were deposited in the GenBank under the accession numbers (MW961513, MW940880, MW94881, MW940882, MW94883, MW961511, MW961510, MW961509, MW961512, MW961514, MW961515, and MW961516). Detailed information of Alignment of the ITS and ITS-sequence of Ascaridoid nematode species present study with their genetic data including reference source, identical $\%$, 
GenBank (ITS) reference, and geographical locality. Accession numbers are provided by NCBI for the collected larvae (Tab. 1).

A comparison of the nucleotide sequences of the rDNA of these species revealed low blast scores with the GenBank (percent identity $=97-100 \%$ ). Alignment of the resulting sequences revealed that there was significant variation in the ITS regions, which indicated the presence of different types of larvae. Characterization of the internal transcribed spacers (ITS) of 13 DNA products, based on percentage identities of nucleotides from GenBank, use the online BLAST tool showed the ITS sequences obtained from larvae belong to eleven distinct taxa (Hysterothylacium spp.) and two specimens of $H$. amoyense. The amplification has been reamplified to confirm. Agarose gels analyses revealed for each ITS region amplicons were 1000 - 1100bp. Detailed information of alignment of the ITS sequence of Ascaridoid nematode species present study with their genetic data including reference source, identical \%, GenBank (ITS)reference, and geographical locality. Two specimens of $H$. amoyense (MW940915) and (MW940896); query similarity identities percentage was: 922/923(99\%) Gaps: 1/923(0\% with H. amoyense (MT020134.1 Length: 955).

Eleven species of Hysterothylacium are recognized, unfortunately, since no mature stages were recorded, it cannot be determined at the species level. The species referred to as Hysterothylacium spp. larvae, because haven't been accurately identified to the species level because it needs to study the mature stage of the parasite, using male and female morphology, and characterization of reproductive organs. Detailed information of alignment of the ITS and ITS-1sequence of anisakid nematode species present study with their genetic data including reference source, identical \%, GenBank (ITS and ITS-1) reference, and geographical locality. Accession numbers provided by NCBI for the collected larvae are shown in Table (1). The recording of this species is the first in the Arab Gulf region and the world where it did not match it in the sequence in the NCBI. Sequence polymorphisms at alignment related are one to nine different positions of the ITS region, and it revealed as different individuals of Hysterothylacium spp. larval type obtained in the present study (Diags. 1-4). It can be considered the $N$. japonicus is a new host record in the world. Besides the most distinguishing characters among Hysterothylacium species based on the differences in length and ratio of digestive tracts of nematodes, viz esophagus length, intestinal caecum, appendage and the ratio of each character to each other, it was noted through the follow-up of the sequence of stillness and the different order of nitrogen bases and electron microscope images that there are clear changes among the species diagnosed in the order of the lips and the installation of folds in the outer wall of the parasite. 
Bannai et al.

Table (1): Detailed information of alignment of the ITS and ITS-sequence of ascaridoid nematode species present study with their genetic data including reference source, identical \%, GenBank (ITS) reference, and geographical locality. Accession numbers are provided by NCBI for the collected larvae.

\begin{tabular}{|c|c|c|c|c|c|c|}
\hline Nematode species & $\begin{array}{l}\text { GenBank } \\
\text { (ITS ) }\end{array}$ & $\begin{array}{r}\text { GenBank } \\
(\text { ITS-1 ) }\end{array}$ & References & Identities \% & $\begin{array}{l}\text { GenBank (ITS) } \\
\text { references }\end{array}$ & $\begin{array}{c}\text { Geograph } \\
\text { ical } \\
\text { locality }\end{array}$ \\
\hline H. amoyense 17 & MW 940896 & MW 961513 & Guo et al. (2020) & $\begin{array}{l}\text { 922/923(99\%), } \\
\text { Gaps: 1/923(0\%) }\end{array}$ & $\begin{array}{l}\text { MT020134.1 } \\
\text { Length: } 955\end{array}$ & China \\
\hline $\begin{array}{l}\text { Hysterothylacium } \\
\text { sp. } 18\end{array}$ & MW961525 & MW940880 & Chen et al.( 2018) & $\begin{array}{l}\text { 925/927(99\%), } \\
\text { Gaps: 2/927(0\%) }\end{array}$ & $\begin{array}{l}\text { MT269312.1 } \\
\text { Length: } 990\end{array}$ & China \\
\hline $\begin{array}{l}\text { Hysterothylacium } \\
\text { sp. } 19\end{array}$ & MW961524 & MW94881 & Zhang et. al. ( 2018) & $\begin{array}{l}\text { 882/900(98\%), } \\
\text { Gaps 9/900(1\%) }\end{array}$ & $\begin{array}{l}\text { MH211527.1 } \\
\text { Length: } 955\end{array}$ & China \\
\hline $\begin{array}{l}\text { Hysterothylacium } \\
\text { sp. } 20\end{array}$ & MW961517 & MW940882 & Zhang et al. (2018) & $\begin{array}{l}\text { 892/904(99\%), } \\
\text { Gaps: 7/904 (0\%) }\end{array}$ & $\begin{array}{l}\text { MH211518.1 } \\
\text { Length: } 955\end{array}$ & China \\
\hline $\begin{array}{l}\text { Hysterothylacium } \\
\text { sp. } 21\end{array}$ & MW961526 & MW94883 & Guo et al. (2020) & $\begin{array}{l}\text { 923/925(99\%), } \\
\text { Gaps: } 1 / 925(0 \%)\end{array}$ & $\begin{array}{l}\text { MT020134.1 } \\
\text { Length: } 955\end{array}$ & China \\
\hline $\begin{array}{l}\text { Hysterothylacium } \\
\text { sp. } 23\end{array}$ & MW961520 & MW 99517 & Guo et al. (2020) & $\begin{array}{l}\text { 911/921(99\%), } \\
\text { Gaps: 4/921(0\%) }\end{array}$ & $\begin{array}{l}\text { MT020134.1 } \\
\text { Length: } 955\end{array}$ & China \\
\hline $\begin{array}{l}\text { Hysterothylacium } \\
\text { amoyense } 24\end{array}$ & MW940915 & MW961511 & Guo et al. (2020) & $\begin{array}{l}\text { 804/805(99\%), } \\
\text { Gaps: 1/805(0\%) }\end{array}$ & $\begin{array}{l}\text { MF539813.1 } \\
\text { Length: } 906\end{array}$ & China \\
\hline $\begin{array}{l}\text { Hysterothylacium } \\
\text { sp. } 25\end{array}$ & MW961523 & MW 961510 & Guo et al. (2020) & $\begin{array}{l}\text { (916/92899\%), } \\
\text { Gaps: 6/928(0\%) }\end{array}$ & $\begin{array}{l}\text { MT020134.1 } \\
\text { Length: } 955\end{array}$ & China \\
\hline $\begin{array}{l}\text { Hysterothylacium } \\
\text { sp. } 26\end{array}$ & MW96 1527 & MW 961509 & Guo et al. (2020) & $\begin{array}{l}\text { 919/926(99\%), } \\
\text { Gaps: 4/926(0\%) }\end{array}$ & $\begin{array}{l}\text { MT020134.1 } \\
\text { Length: } 955\end{array}$ & China \\
\hline $\begin{array}{l}\text { Hysterothylacium } \\
\text { sp. } 27\end{array}$ & MW961518 & MW 961512 & Guo et al. (2020) & $\begin{array}{l}\text { 903/929(97\%), } \\
\text { Gaps8/929 (0\%) }\end{array}$ & $\begin{array}{l}\text { MT020134.1 } \\
\text { Length: } 955\end{array}$ & China \\
\hline $\begin{array}{l}\text { Hysterothylacium } \\
\text { sp. } 28\end{array}$ & MW961519 & MW 961514 & Guo et al. (2020) & $\begin{array}{l}\text { 916/927(99\%), } \\
\text { Gaps: 5/927 (0\%) }\end{array}$ & $\begin{array}{l}\text { MT020134.1 } \\
\text { Length: } 955\end{array}$ & China \\
\hline $\begin{array}{l}\text { Hysterothylacium } \\
\text { sp. } 29\end{array}$ & MW 961522 & MW 961515 & Guo et al. (2020) & $\begin{array}{l}\text { 920/930(99\%), } \\
\text { Gaps: 8/930 (0\%) }\end{array}$ & $\begin{array}{l}\text { MT020134.1 } \\
\text { Length: } 955\end{array}$ & China \\
\hline $\begin{array}{l}\text { Hysterothylacium } \\
\text { sp. } 30\end{array}$ & MW 961521 & MW 961516 & Guo et al. (2020) & $\begin{array}{l}\text { 921/929(99\%), } \\
\text { Gaps: 5/929(0\%) }\end{array}$ & $\begin{array}{l}\text { MT020134.1 } \\
\text { Length: } 955\end{array}$ & China \\
\hline
\end{tabular}


Query: A17_NC5 Query ID: lcl|Query_442915 Length: 922

Sequence ID: MT020134.1 Length: 955 Range 1: 31 to 953 Score 1698 bits(919), Expect:0.0, Identities 922/923(99\%), Gaps:1/923(0\%), Strand: Plus/Plus

Query 1 TCTCCG-

ACGTGCATGCCTTCCATGTGCGCGTATACGTGAGCCGCGCAGCAAGTTGCACA 59

Sbjct 31 90

Query 900 CCCGCTGAATTTAAGCATATAAC 922

Sbjct 931 953

Query: A18_NC5 Query ID: 1c1|Query_64135 Length: 927

Sequence ID: MT269312.1 Length: 990 Range 1: 46 to 971 Score 1700 bits (920), Expect:

0.0

Identities 925/927(99\%), Gaps: 2/927(0\%), Strand: Plus/Plus

Query 1 TCTCCG-

ACGTGCATGCCTTCCATGTGCGCGTATACGTGAGCCGCGCAGCAAGTTGCACA 59

Sbjct 46 105

Query 900 ACCCGCTGAATTTAAGCATATAACTAA 926

Sbjct 945 971

Query: A19_NC5 Query ID: lcl|Query_46107 Length: 927

Sequence ID: MH211527.1 Length: 955, Range 1: 31 to 922 , Score 1554 bits(841),

Expect:0.0,

Identities 882/900(98\%), Gaps 9/900(1\%), Strand: Plus/Plus

Query 1 TCTCCG-

ACGTGCATGCCTTCCATGTGCGCGTATACGTGAGCCGCGCAGCAAGTTGCACA 59

Sbjct 31 90

Query 780

GTTGCTCTGTTGGTGGTGTGGTGGTGAAAAAGGGTTTTGTTTGGGATGCATGCTTC CACG 839

Sbjct 811 .T.T-.. A..G.A 866

Query 840

GTTAGTGATTGAGAGTGATGCGAAGGTGGCTATCGCCTCTGTTTGGGACCTCAGG TCAGT 899

Sbjct 867 .C .T.-....T-............. 922

Query: A20_NC5 Query ID: lc1|Query_12519 Length: 904

Sequence ID: MH211518.1 Length: 955, Range 1: 41 to 937, Score 1596 bits(864),

Expect:0.0,

Identities 892/904(99\%), Gaps: 7/904(0\%), Strand: Plus/Plus

Query 1

TGCATGCCTTCCATGTGCGCGTATACGTGAGCCGCGCAGCAAGTTGCACACATGT GGTGG 60

Sbjct 41 100

Query 781

TGGTGGTGTGGTGGGGATAATGGGGTTGTGTTTGGGAATGCATGCATCAAACAGT TAGTG 840
Sbjct 821 T. G-....C..... 873

Query 841

ATGAGAGTGATGCGAGGTGGCTATCGCTCTGTTTTGACCTCAGCTCAGTCGTGAC

TACTC 900

Sbjct 874 ...........................T.............................. 933

Query 901 GCTG 904

Sbjct $934 \ldots . .937$

Query: A21_NC5 Query ID: 1cl|Query_21131 Length: 926 
Bannai et al.

Sequence ID: MT020134.1 Length: 955, Range 1: 31 to 955, Score 1696 bits (918), Expect: 0.0

Identities 923/925(99\%), Gaps: 1/925(0\%), Strand: Plus/Plus

Query 1 TCTCCG-

ACGTGCATGCCTTCCATGTGCGCGTATACGTGAGCCGCGCAGCAAGTTGCACA 59

Sbjct 31 90

Query 780

GTTGCTCTGTTGGTGGCGTGGTGGTGATATGGTTTGTTTGGATGCATGCATCGACA

GCTA 839

Sbjct 811 .T. 870

Query 840

GTGATGAGAGTGATGCGAGGTGGCTATCGCTTTGTTTTGACCTCAGCTCAGTCGT GACTA 899

Sbjct 871 930

Query 900 CCCGCTGAATTTAAGCATATAACTA 924

Sbjct 931 955

Diagram (1): Details sequence polymorphisms pairwise with dots for identifies similarity at the alignment of the ITS sequences representing genotype from the present study, and genotype NCBI blast scores: 1- $H$. amoyense (MW94896), 2- Hysterothylacium sp. (MW961525), 3Hysterothylacium sp. (MW961524), 4- Hysterothylacium sp. (MW961517), 5- Hysterothylacium sp. (MW961526).

Query: A23_NC5 Query ID: 1c1|Query_43761 Length: 919

Sequence ID: MT020134.1 Length: 955, Range 1: 31 to 949, Score 1642 bits(889),

Expect:0.0,

Identities 911/921(99\%), Gaps:4/921(0\%), Strand: Plus/Plus

Query 1

TCTCCGAGCGTGCATGCCTTCCATGTGCGCGTATACGTGAGCCGCGCAGCAAGTT GCACA 60

Sbjct 31 90

Sbjct 811

Query 841 TAGTGATGATAGTGATGCGAGGTGGCTATCGCTTTG-

TTTGACCTCAGCTCAGTCGTGAC 899

Sbjct 869 .......................................................... 928

Query 900 TACTTGGTGA-TTTAAGAATA 919

Sbjct 929 ...CC.C...A.......... 949

Query: A24_NC5 Query ID: lcl|Query_472435 Length: 804

Sequence ID: MF539813.1 Length: 906, Range 1: 31 to 835, Score 1480 bits(801), Expect:0.0, Identities 804/805(99\%), Gaps:1/805(0\%), Strand: Plus/Plus

Query 1 TCTCCG-

ACGTGCATGCCTTCCATGTGCGCGTATACGTGAGCCGCGCAGCAAGTTGCACA 59

Sbjet 31 ...................................................... 90

Query 780 GTTGCTCTGTTGGTGGTGTGGTGGT 804

Sbjct 811 835

Query: A25_NC5 Query ID: lcl|Query_45659 Length: 927

Sequence ID: MT020134.1 Length: 955, Range 1: 31 to 953, Score:1642 bits(889),

Expect:0.0,

Identities: (916/92899\%), Gaps: 6/928(0\%), Strand: Plus/Plus 
Query 1 TCTCCG-

ACGTGCATGCCTTCCATGTGCGCGTATACGTGAGCCGCGCAGCAAGTTGCACA 59 Sbjct 31 90

Query 780

GTTGCTCTGTTGGTGGTGTGGTGGGAAAAAAGGGGTTTGGTTTGGGATGCATGCA TCGAC 839

Sbjct 811 TG.T.T865

Query 840

GGTTAGTGATGAGAGTGATGCGAGGTGGCTATCGCTTTGTTTTGACCTCAGCTCA GTCGT 899

Sbjct 866 A.C. 925

Query 900 GACTACCCGCTGAATTTAAGCATATAAC 927

Sbjct 926 953

Query: A26_NC5 Query ID: 1cl|Query_15851 Length: 925

Sequence ID: MT020134.1 Length: 955, Range 1: 31 to 953, Score 1668 bits(903),

Expect:0.0,

Identities 919/926(99\%), Gaps: 4/926(0\%), Strand: Plus/Plus

Query 1 TCTCCG-

ACGTGCATGCCTTCCATGTGCGCGTATACGTGAGCCGCGCAGCAAGTTGCACA 59 Sbjct 31 90

Query 780

GTTGCTCTGTTGGTGGTGTGGTGGTGAAAAAGGGTTTGGTTTGGATGCATGCATC GACGG 839

Sbjct 811 T.T-..... A. 867

Query 840

CTAGTGATGAGAGTGATGCGAGGTGGCTATCGCTTTGTTTTGACCTCAGCTCAGT CGTGA 899

Sbjct 868 927

Query 900 CTACCCGCTGAATTTAAGCATATAAC 925

Sbjct 928 953

Diagram (2): Details sequence polymorphisms pairwise with dots for identifies similarity at the alignment of the ITS sequences representing genotype from the present study, and genotype NCBI blast scores: 1Hysterothylacium sp. (MW961520), 2- H. amoyense (MW940915), 3Hysterothylacium sp. (MW961523), 4- Hysterothylacium sp. (MW961527), 5- Hysterothylacium sp. (MW961518).

Query: A27_NC5 Query ID: lc1|Query_53213 Length: 927

Sequence ID: MT020134.1 Length: 955, Range 1: 31 to 953, Score: 1565 bits (847), Expect: 0.0 ,

Identities 903/929(97\%), Gaps: 8/929(0\%), Strand: Plus/Plus

Query 1 TCTCCG-

ACGTGCATGCCTTCCATGTGCGCGTATACGTGAGCCGCGCAGCAAGTTGCACA 59 Sbjct 31 .......A. 90

Query 780 GTTGCTCTGTTG-

TGGTGTGGGGGGAAAAAGGGGGttttttGGAATGCAGGAAATAAAA 838

Sbjct 811 .....................T..TG.T.T..---...G..........T.C.TCG.C. 866

Query 839

GGTTATTGATGAAAAGTGATGCAAGGTGGTTATGGCTTTGTTTTGACCTCAGCTC AGTCG 898 
Sbjct 867 .C.-.G......G-........G.................................. 924

Query 899 TGACTACCCGCTGAATTTAAGCATATAAC 927

Sbjct 925 953

Query: A28_NC5 Query ID: 1cl|Query_94039 Length: 1329

Sequence ID: MT020134.1 Length: 955, Range 1: 32 to 954, Score 1646 bits (891), Expect:

0.0 ,

Identities: 916/927(99\%), Gaps: 5/927(0\%), Strand: Plus/Plus

Query 1 CTCCG-

ACGTGCATGCCTTCCATGTGCGCGTATACGTGAGCCGCGCAGCAAGTTGCACAC 59

Sbjet 32 .....A. 91

Query 780

TTGCTCTGTtggtggtggtggtggtgAAAATGGTTTGGTTTGGATGCATGCCATCAACAG

839

Sbjct 812

T. G.... 867

Query 840

CTATTGATGAAAGTGATGCGACGTGGCTATCGCTTTGTTTTGACCTCAGCTCAGTC

GTGA 899

Sbjct 868 ...G......G............................................ 927

Query 900 CTACCCGCTGAATTTCAGCATATAACT 926

Sbjct 928 ........................... 954

Query: A29_NC5 Query ID: lcl|Query_22587 Length: 930

Sequence ID: MT020134.1 Length: 955, Range 1: 31 to 955, Score 1655 bits(896),

Expect:0.0,

Identities 920/930(99\%), Gaps: 8/930(0\%), Strand: Plus/Plus

Query 1 TCTCCG-

ACGTGCATGCCTTCCATGTGCGCGTATACGTGAGCCGCGCAGCAAGTTGCACA 59 Sbjct 31 ....................................................... 90

Query 780 GTTGCTCTGTTGGTGGTGTGG-G-

TGATAAGGGGGTTTGTTTTGGAATGCATGCATCAAC 837

Sbjct 811 ...................T.G.....T..---..........-............. 865

Query 838

AGCTAGTGATGAGAGTGATGCGAGGTGGCTATCGCTTTGTTTTGACCTCAGCTCA

GTCGT 897

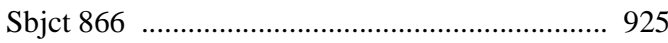

Query 898 GACTACCCGCTGAATTTAAGCATATAACTA 927

Sbjct 926 955

Diagram(3): Details sequence polymorphisms pairwise with dots for identifies similarity at the alignment of the ITS sequences representing genotype from the present study, and genotype NCBI blast scores: 1- Hysterothylacium sp. ( MW961519), 2- H. amoyense (MW940915), 3- Hysterothylacium sp. (MW961522).

Query: A30_NC5 Query ID: lcl|Query_55461 Length: 931

Sequence ID: MT020134.1 Length: 955, Range 1: 31 to 955, Score 1666 bits (902), Expect: 0.0 ,

Identities 921/929(99\%), Gaps: 5/929(0\%), Strand: Plus/Plus 
Query 1

TCTCCGCGCGTGCATGCCTCTCCATGTGCGCGTATACGTGAGCCGCGCAGCAAGT TGCAC 60

Sbjct 31 89

Query 781 TGTTGCTCTGTTGGTGGTGTGGTG-

TGAATATGGGTTTGGTTTGGATGCATGCATCGACA 839

Sbjct 810 866

Query 840

GCTAGTGATGAGAGTGATGCGAGGTGGCTATCGCTTTGTTTTGACCTCAGCTCAG TCGTG 899

Sbjet 867

Query 900 ACTACTCGCTGAATTTAAGCATATAACTA 928

Sbjet $927 \ldots . . . \mathrm{C}$ 955

Diagram (4): Details sequence polymorphisms pairwise with dots for identifies similarity at the alignment of the ITS genotype from the present study, and genotype NCBI blast scores of Hysterothylacium sp. (MW961521 sequences representing).

\section{Phylogenetic analysis}

The evolutionary history was inferred by using the Maximum Likelihood method and Tamura-Nei model. The tree with the highest log likelihood (-9072.97) is shown. Initial tree(s) for the heuristic search were obtained automatically by applying Neighbor-Join and BioNJ algorithms to a matrix of pairwise distances estimated using the Tamura-Nei model, and then selecting the topology with a superior log likelihood value. The tree is drawn to scale, with branch lengths measured in the number of substitutions per site (next to the branches). The proportion of sites where at least 1 unambiguous base is present in at least 1 sequence for each descendent clade is shown next to each internal node in the tree. This analysis involved 14 nucleotide sequences. There were a total of 1329 positions in the final dataset. Our results revealed that the Hysterothylacium nematodes selected for the phylogenetic tree of 13 gene sequences species constructed with maximum likelihood (ML), were divided into 6 major clades grouped with strong support in clades one, It represents the largest gene diversity of this type of fish, showed that exhibit a very close relationship. whereas other clades represent another diversity of families of the Raphidascarididae (Diag. 5). 

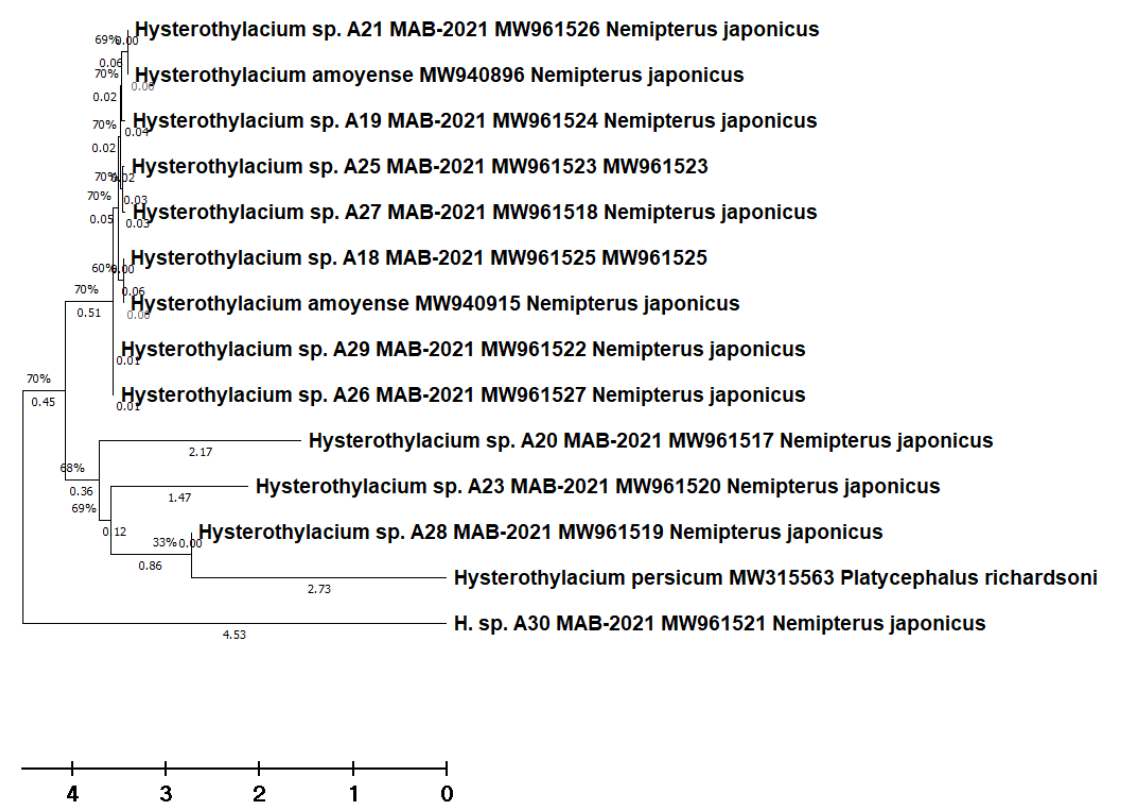

Diagram (5): (Maximum likelihood (ML) Phylogenetic relationships between characterization diversity of ascaridoid nematodes of $N$. japonicus larvae obtained in the present study and another Database of NCBI species. This analysis involved 14 nucleotide sequences. There were a total of 1329 positions in the final dataset. $H$. persicum was used as an outgroup.

The genus Nemipterus Swainson, 1839, is the largest in the family Nemipteridae, and consider as important as a food source (Russell, 1990). by following many studies around the world, it has been found that these fish are endemic to different marine environments. Through the review of many scientific sources and studies on food, in addition to the results of the current study, snails, starfish, and shrimps are an important source of fish nutrition, This high food diversity is the source of a wide variety of infections.

Many studies have been conducted on the detection of internal parasites, including larval stages, from these studies carried out by Dadar et al. (2016) who reported "the occurrence of ascaridoid nematodes from N. japonicus in the Arabian Gulf". Also, Nematollahi et al. (2018) examined 649 N. japonicus for helminth parasites in the Arabian Gulf (also off Boushehr, Iran). $N$. japonicus is an important marine food fish in Asia. However, knowledge of the occurrence of its nematode parasites is still limited, the species composition and infection rate of ascaridoid nematodes in $N$. japonicus from the South China Sea were studied for the first time by Guo et al. (2020), recorded five ascaridoid species, namely Anisakis typica (L3), Hysterothylacium amoyense (L3), Hysterothylacium sp. IV-A (L3), an adult of $H$. thalassini Bruce, 1990 and Raphidascaris lophii (Wu, 1949) Hartwich, 1975. 
Molecular characterization of anisakid nematodes

The present study matched one of its aspects with that of a recent study in China by recording two types of nematode parasites, H. amoyense (L3), and Hysterothylacium sp. (L3). As well as the results of the Guo et al., (2020) study consider the species $H$. amoyense as the most prevalent species were found in the South China Sea. This is exactly what corresponds to the results of the current study if it is found that the H. amoyense is prevalent species in $N$. japonicus off Iraq.

Species of Hysterothylacium are common nematode parasites of marine fishes worldwide (Guo et al., 2014). Marine fishes can act as both the paratenic/intermediate and/or the definitive hosts of Hysterothylacium spp. (Køie, 1993). Various studies demonstrated that internal transcribed spacers (ITS, ITS-1, and ITS's-2) of the nuclear ribosomal DNA (rDNA) provide genetic markers for the accurate identification of a range of species of Ascaridoids. Also, more studies indicated that sibling species can be differentiated based on the ITS sequences (Zhou et al., 2002). In the current study, significant changes were observed, The prevalence of some species of parasites that were related to the genus Anisakis in the study area has absent when compared to other previous studies in this region, perhaps due to environmental changes, through high temperatures or salinity concentration values, which are important and specific factors for hatching some species of parasites, the rarity of the final host.

The prevalence of infection in intermediate hosts varies greatly, depending on the hosts and age, as well as on the fishing area. This was recorded when compared with studies conducted outside the sampling area in the Arabian Gulf region or open water from the Indian Ocean and adjacent seas. Higher infections with Raphidascarididae were found than that observed by Shamsi et al. (2016) in Bander Abas, Hormozan province, off Arabian Gulf. Their study of "600 fish belonging to five popular species of fish. The important studies in Arabian Gulf regions were carried out by Al-Salim and Ali (2010), Ghadami et al. (2017), and Zhao et al. (2017) from marine fish in Iraqi waters). What they found was that "the Hysterothylacium species are perhaps the most abundant and diverse group of marine ascaridoid". This also corresponds to the results of the current study.

The prevalence of $H$. amoyense in different types of fishes reported by and Chen et al. (2018) and Guo et al. (2020) that were found in the present study were similar. We also found some distinct morphology and ITS sequences but due to a lack of adult specimens. Unfortunately, we are referred to as Hysterothylacium spp. because we haven't accurately identified the species level due to it needs to study the mature stage of the parasite, using male and female morphology, and characterization of reproductive organs.

\section{CONCLUSIONS}

Although, the specific broad studies of molecular characterization of ascaridoid nematodes and their larval stages in many parts of the world, the Arabian Gulf nematodes diversity, particularly in Iraqi marine waters, have not been completely understood. Our study provided some insights into the taxonomy and systematics of these parasites, also support similar studies elsewhere both morphological methods and molecular approaches to accurately 
Bannai et al.

identify large numbers and to determine the abundance, diversity, and infection levels of anisakid nematodes off northwest Arabian Gulf fishery, Iraq, In light of these variables, it has become clear that it is necessary to conduct more cooperation study, with scientific teams in the regions referred to above to study the genetic diversity of ascaridoid to identify its most important species.

\section{ACKNOWLEDGMENT}

This study was supported by the Department of Veterinary Microbiology and Parasitology, College of Veterinary Medicine, and Marine Science Centre, University of Basrah, Iraq.

\section{CONFLICT OF INTEREST STATEMENT}

We are the authors of the submitting manuscript, declare and confirm that no significant financial or other relationship with any providers of commercial services discussed in the manuscript and any financial supporters of the research.

\section{LITERATURE CITED}

Albadran, B. 2004. Shatt Al-Arab Delta, Southern Iraq, sedimentological study Marine Mesopotamia, 19 (2): 311-322.

Ali, A. H., Mhaisen, F. T. and Khamees, N. R. 2014. Checklists of nematodes of freshwater and marine fishes of Basrah Province, Iraq. Mesopotamia Journal of Marine Science, 29(2):71-96.

Anderson, R. C. 2000. Nematode parasites of vertebrates: Their development and transmission. CABI, $672 \mathrm{pp}$.

Al-Salim, N. K. and Ali, A. H. 2010. Description of eight nematode species of the genus Hysterothylacium Ward et Magath, 1917 parasitized in some Iraqi marine fishes. Basrah Journal of Agriculture and Science, 23 (special 1): 115-137.

Bannai, M. A. 2018. Hysterothylacium persicum (Nematoda: Raphidascarididae) parasite of orange-spotted grouper Epinephelus coioides (Forsskål, 1775) Iraqi marine water fishes. Iraqi Journal of Science, 59(C): 1548-1553.

Chen, H.-X., Zhang, L.-P., Gibson, D.I., Lü, L., Xu, Z., Li, H.-T., Ju, H.-D.and Li, L. 2018. Detection of ascaridoid nematode parasites in the important marine food-fish Conger myriaster (Brevoort) (Anguilliformes: Congridae) from the Zhoushan fishery, China. Parasite Vectors, 11: 274-285.

Dadar, M., Alborzl, A., Peyghan, R. and Adel, M. 2016. Occurrence and intensity of anisakid nematode larvae in some commercially important fish species in the Persian Gulf. Iranian Journal of Parasitology, 11: 239-246. 
Molecular characterization of anisakid nematodes

Froese, R. and Pauly, D. 2021. FishBase. World Wide Web electronic publication version (6/2021). Available at: www.fishbase.org.

Ghadami, M., Bannai, M., Mohammed, E.T., Sutha, J. and Shamsi, S. 2017. Morphological and molecular characterization of selected species of Hysterothylacium (Nematoda: Raphidascarididae) from marine fish in Iraqi waters, Journal of Helminthology. 92 (1): $116-124$.

Guo, Y-N., Xu, Z., Zhang, L-P., Hu, Y-H., and Li, L. 2014. Occurrence of Hysterothylacium and Anisakis nematodes (Ascaridida: Ascaridoidea) in the Tanaka's snailfish Liparis tanakae (Gilbert \& Burke) (Scorpaeniformes: Liparidae). Parasitololgy Reserch, 113(4): 1289-1300.

Guo, N., Chen, H.-X., Zhang, L.-P., Zhang, J.-Y., Yang, L.-Y. and Li, L. 2020. Infection and molecular identification of ascaridoid nematodes from the important marine food fish Japanese threadfin bream Nemipterus japonicus (Bloch) (Perciformes: Nemipteridae) in China. Infection Genetics and Evolution, 85:104562.

Jabbar, A. Asnoussi, A, Norbury, LJ. Eisenbarth, A. Shamsi, S. Gasser, R. B., Lopata, A. L., and Beveridge, I._2012. Larval anisakid nematodes in teleost fishes from Lizard Island, northern Great Barrier Reef, Australia. Marine and Freshwater Research, 63(12):1283-1299.

Køie, M. 1993. Aspects of the life-cycle and morphology of Hysterothylacium aduncum Rudolphi, 1802) (Nematoda, Ascaridoidea, Anisakidae). Canadian Journal of Zoology, 71:1289-1296.

Krasnovyd, V., Vetešník, L. and Šimková, A. 2020. Distribution of host-specific parasites in hybrids of phylogenetically related fish: the effects of genotype frequency and maternal ancestry. Parasites Vectors, 13 (402):2-11.

Kumar, S., Stecher, G., Li, M., Knyaz, C. and Tamura, K. 2018. Molecular evolutionary genetics analysis across computing platforms. Molecular Biology and Evolution, 35:1547-1549.

Moravec F. 2004. Some aspects of the taxonomy and biology of dracunculoid nematodes parasitic in fishes: a review. Folia Parasitologica, 51(1):1-13.

Moravec, F. and Yooyen, T. 2011. Two new species of Rhabdochona (Nematoda: Rhabdochonidae) from freshwater fishes in Thailand. Folia Parasitologica, 58(3): 224-32. 
Bannai et al.

Moravec, F., Walter, T. and Trisnani, A. 2012 . Five new species of philometrid nematodes (Philometridae) from marine fishes off Java, Indonesia. Folia Parasitology, 59 (2): 115-130.

NCBI. 2020. National Center for Biotechnology Information. Available at: (https://blast.ncbi.nlm.nih.gov/Blast.cgi).

Nematollahi, A., Shahbazi, P., Abbasi, M. F., Ghaemmaghami, S. and Mobedi, I. 2018. The first report of nematode (Contracaecum) and two Acanthocephala (Serrasentis sagittifer, Tenuiosentis niloticus) in Persian Gulf's Japanese threadfin bream (Nemipterus japonicus). Comparative Clinical Pathology, 27: 1303-1307.

Poulin, R. and Morand, S. 2004. Parasite Biodiversity. Smithsonian Books, Washington, DC, USA, $216 \mathrm{pp}$.

Russell, B. C. 1990. FAO species catalogue. Vol.12. Nemipterid fishes of the world (threadfin breams, whiptail breams, monocle breams, dwarf monocle breams and coral breams), family Nemipteridae. An annotated and illustrated catalogue of nemipterid species known to date. FAO Fisheries Synopsis, FAO, Rome, 149 pp.

Shamsi, S. 2016. Morphometric and molecular descriptions of three new species of Hysterothylacium (Nematoda: Raphidascarididae) from Australian marine fish. Journal of Helminthology, 91(5): 613 - 624.

Shamsi, S., Gasser, R. and Beveridge, I. 2013. Description and genetic characterization of Hysterothylacium (Nematoda: Raphidascarididae) larvae parasitic in Australian marine fishes. Parasitology International, 62: 320-328.

Shamsi, S., Gasser, R., Beveridge, I. and Shabani, A. A. 2008. Contracaecum pyripapillatum n. sp. and a description of C. multipapillatum (von Drasche, 1882) from the Australian pelican, Pelecanus conspicillatus. Parasitology Research, 103: 1031-1039.

Shamsi, S., Ghadam, M., Suthar, J., Ebrahimzadeh Mousavi, H., Soltani, M. and Mirzargar, S. 2016. Occurrence of ascaridoid nematodes in selected edible fish from the Persian Gulf and description of Hysterothylacium larval type XV and Hysterothylacium persicum n. sp. (Nematoda: Raphidascarididae). International Journal of Food and Microbiology, 236: 65-73.

Spratt, D. M. 1997. Endoparasite control strategies: implications for biodiversity of native fauna. International Journal of Parasitology, 27(2):173-80.

WoRMS. 2021. World Register of Marine Species. Available at: http://www.marinespecies.org. 
Molecular characterization of anisakid nematodes

Zhang, K., Xu, Z., Chen, H. X., Guo, N. and Li, L. 2018. Anisakid and raphidascaridid nematodes (Ascaridoidea) infection in the important marine food-fish Lophius litulon (Jordan) (Lophiiformes: Lophiidae). International Journal of Food Microbiology, 284:105-111.

Zhang, L., Hu, M., Shamsi, S., Beveridge, I., Li, H., Xu, Z., Li, L., Cantacessi, C. and Gasser, R. B. 2007. The specific identification of anisakid larvae from fishes from the yellow sea, China, using mutation scanning-coupled sequence analysis of nuclear ribosomal DNA. Molecular and Cell Probes, 21(5): 386-390.

Zhao, J. Y., Zhao, W. T., Ali, A. H., Chen, H.-X. and Li, L. 2017. Morphological variability, ultrastructure, and molecular characterization of Hysterothylacium reliquens (Norris and Overstreet, 1975) (Nematoda: Raphidascarididae) from the oriental sole Brachirus orientalis (Bloch \& Schneider) (Pleuronectiformes: Soleidae). Parasitology International, 66: 831-838.

Zhou, L., Wang, P. X., Huang, F, Cao, L. Y. and Liang, R. Y. 2002. ITS sequence analysis of Amomum villosum. Chinese Traditional and Herbal Drugs, 33: 72-75. 
التوصيف الجزيئي لأنواع النيماتودا Anisakid Nematodes ضمن جنس Hysterothylacium Nemipterus Japanius (Bloch, 1791) (Perciformes, Nemiperidae)

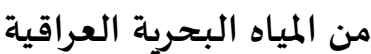

ماجد عبد العزيز بناي* ، منى محمد جوري **و شـاكوفيش شمسي*** *قسم الفقريات البحرية ، مركزعلوم البحار، جامعة البصرة، البصرة، العراق. **فرع الأحياء المجهرية البيطرية والطفيليات، كلية الطب البيطري، جامعة البصرة،

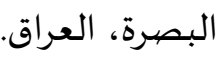

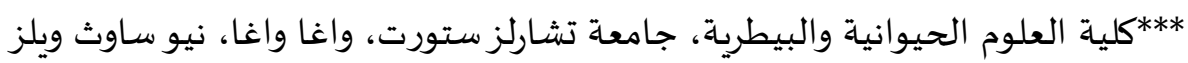
2678، أستراليا.

تأريخ الاستلام: 2021/05/08، تأريخ القبول: 2021/07/25، تأريخ النشر: 2021/12/20

\section{الخلاصة}

قدمت هذه الدراسة نظرة جديدة على المعلومات القيمة حول البنية المتنوعة لسكان الأسكاريدويد وتناقش ثراء الأنواع المحدود في أسماك النوع Nemipterus Nemiperidae رتبة Paponicas (Bloch, 1791)

تتكون منطقة الصيد من مواقع مختلفة في الخليج العربي (58²9 033 N48²8 0 E00 أصيبت بالعدوى. عزلت مراحل اليرقات (n = 763) المنتشرة داخل الأحشاء من أعضاء الأسماك ، مع نسبة اصابة 91.11\% ، وكانت شدة الإصابة 2.65. 
أُجري التحليل الجزيئي على ثلاثين فردا من الذين فحصهوا مظهريا، التي أظهرت بعض الاختلافات، عن طريق تضخيم منطقة ITS و ITS-1 من rDNA النووية (rDNA) بواسطة PCR باستخدام مجموعات البرايمر التمهيدي NC5/NC2 و SS1/NC13R. وأجريت تحليلات تطورية في MEGA X؛ واستنادا إلى قاعدة التشابة في البنك الجيني في قاعدة بيانات جينبانك أظهرت أهها تنتهي إلى الديدان الخيطية أنيساكيد، على وجه الخصوص؛ وانها تنتهي إلى أحد عشر صنيفا taxa متميزا من جنس Hysterothylacium

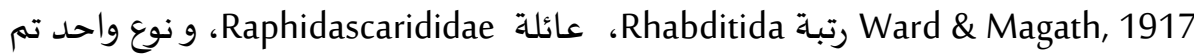
تحديده متمثلا بالنوع H. amoyense (Hü̈, 1933) Deardorff \& Overstreet, 1980) سُجل في الدراسة الحالية أحد عشر نوعا من Hysterothylacium، بعض من محاذاة تسلسل تعدد الأشكال، كشفت عن أفراد مختلفين جدد من أنواع اليرقات التي يمكن اعتمادها كنوع جديد، إذا تم الكشف عن الاطوار الكاملة، وان N. japonicus هو مضيف جديد في العالم، كما تقدم الدراسة الحالية بعض المفاهيم حول تصنيف هذه الطفيليات ، بالإضافة إلى ذلك ، تدعم دراسات مماثلة تم نشرها في أماكن أخرى من

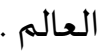

